THE EFFECT OF PARTICIPATION OF BUDGET-BASED PERFORMANCE (ABK) BUDGETS ON

THE PERFORMANCE OF THE REGIONAL GOVERNMENT SKPD HEALTH: ORGANIZATIONAL COMMITMENTS AND LEADERSHIP STYLES AS MODERATING VARIABLES

(SURVEY IN THE GOVERNMENT OF JAMBI PROVINCE)

\title{
PENGARUH PARTISIPASI PENYUSUNAN ANGGARAN BERBASIS KINERJA (ABK) TERHADAP \\ KINERJA KEPALA SKPD PEMERINTAH DAERAH: KOMITMEN ORGANISASI DAN GAYA \\ KEPEMIMPINAN SEBAGAI VARIABEL MODERATING \\ (SURVEY PADA APARATUR PEMERINTAH \\ PROVINSI JAMBI)
}

\author{
Doli Candra' ${ }^{1)}$, Zamzami $^{2)}$, Muhammad Gowon ${ }^{3)}$ \\ 1)Alumni Magister Ilmu Akuntansi Pascasarjana Universitas Jambi Tahun 2019 \\ ${ }^{2 \& 3)}$ Dosen Pembimbing
}

\begin{abstract}
This research aimed to explain the effect of performance based budgetary participation on performance of the head of local authority units on local government with organizational commitment and leadership style as moderating variables. Survey had been conducted to the 88 civil servants of Jambi city who involved on budgetary. The analysis method used is Moderated Regression Analysis (MRA) with SPSS $22^{\text {nd }}$ version. The result of this research was budgetary participation had effect on performance of the head of local authority unit. Organizational commitment was able to moderate the effect of budgetary participation on the head of local authority unit performance of local government. However, leadership style was not able to moderate the effect of budgetary participation on Performance of The head of Local Authority Unit.
\end{abstract}

Keywords: Performance based Budgetary Participation, Organizational Commitment, Leadership Style, and Local Authority Units Head Performance on Local Government.

\begin{abstract}
ABSTRAK
Penelitian ini bertujuan untuk menjelaskan pengaruh partisipasi penyusunan anggaran berbasis kinerja (ABK) terhadap kinerja kepala SKPD pemerintah daerah dengan komitmen organisasi dan gaya kepemimpinan sebagai variabel moderating. Survey dilakukan terhadap 88 aparatur SKPD Pemerintah Provinsi Jambi yang terlibat dalam penyusunan anggaran. Metode analisis yang digunakan adalah MRA (Moderated Regression Analysis) dengan SPSS versi 22. Hasil penelitian ini adalah partisipasi penyusunan anggaran berpengaruh terhadap Kinerja Kepala SKPD Pemerintah Daerah, Komitmen Organisasi mampu memoderasi mengenai pengaruh partisipasi penyusunan anggaran terhadap Kinerja Kepala SKPD Pemerintah Daerah. Namun, gaya kepemimpinan tidak mampu memoderasi pengaruh partisipasi penyusunan anggaran terhadap Kinerja Kepala SKPD Pemerintah Daerah.
\end{abstract}

Kata Kunci: Partisipasi Penyusunan Anggaran berbasis Kinerja, Komitmen Organisasi, Gaya Kepemimpinan, dan Kinerja Kepala SKPD Pemerintah Daerah. 


\section{PENDAHULUAN}

\subsection{Latar Belakang Penelitian}

Berdasarkan Undang-Undang Nomor 23 tahun 2014 tentang Pemerintahan Daerah, penyelenggaraan urusan pemerintahan oleh daerah otonom sesuai dengan asas densentralisasi menjadi tanggungjawab dan tugas unsur penyelenggara pemerintah daerah yang meliputi Gubernur, Bupati atau Walikota dan Perangkat Daerah dengan tujuan untuk meningkatkan pelayanan publik, kesejahteraan umum dan daya saing daerah (PP Nomor 41 Tahun 2007).

Desentralisasi peran dan tanggung jawab yang nyata kepada pemerintah daerah, diharapkan dapat membuat sektor publik lebih tanggap terhadap kebutuhan-kebutuhan dan prioritas masyarakat di daerah. Tercapainya tujuan tersebut sangat bergantung pada kemampuan aparatur daerah dalam menjalankan fungsi-fungsinya. Salah satu fungsi adalah merumuskan perencanaan strategis ke dalam tujuan jangka pendek, jangka menengah dan jangka panjang. Hal ini menjadikan masalah anggaran relevan dan penting, sebab anggaran merupakan alat bagi pemerintah untuk mengarahkan pembangunan sosial ekonomi, menjamin kesinambungan dan meningkatkan kualitas hidup masyarakat.

Menyadari berbagai kelemahan dari sistem penganggaran yang lama, maka telah ditetapkan Undang-Undang Nomor 17 Tahun 2003 tentang Keuangan Negara. Berdasarkan undang-undang tersebut setiap Satuan Kerja Perangkat Daerah (SKPD) dilibatkan dalam proses penyusunan Rencana Kerja Anggaran (RKA-SKPD). Sistem penganggaran dibangun dengan memadukan perencanaan kinerja dengan anggaran tahunan sehingga terlihat adanya keterkaitan antara dana yang tersedia dengan hasil yang diharapkan.

Penelitian mengenai hubungan partisipasi dalam penyusunan anggaran dengan kinerja telah banyak dilakukan. Namun hasil penelitian-penelitian tersebut kebanyakan memberikan bukti empiris yang tidak konsisten dan bervariasi antara partisipasi dalam penyusunan anggaran dengan kinerja. Misalnya penelitian yang dilakukan oleh Raghunandan dkk (2012), Kewo (2014), dan Darman (2015) menemukan partisipasi dalam penyusunan anggaran memiliki hubungan positif dengan kinerja. Sedangkan peneliti lain seperti Fitri (2016), dan Rachman (2014) menemukan partisipasi penyusunan anggaran tidak berpengaruh terhadap kinerja, Syahputra (2014) menemukan bahwa tidak terdapat hubungan signifikan antara partisipasi dalam penyusunan anggaran dengan kinerja.

Baihaqi (2012), Kholidah dan Martini (2014) dan Noor dan Othman (2012) Komitmen organisasi memiliki pengaruh positif signifikan terhadap hubungan partisipasi anggaran dengan kinerja. Sedangkan Utama dan Rohman (2015), dan Hashim dkk (2014) menyatakan Komitmen Organisasi tidak berpengaruh signifikan terhadap kinerja. Wulandari dan Riharjo (2016) menunjukan komitmen organisasi tidak dapat memoderasi pengaruh pengaanggaran partisipatif terhadap kinerja.

Penelitian Nor (2007), Eka dan Adiguna (2014), dan Yumani dkk (2007) menunjukkan Partisipasi anggaran dan gaya kepemimpinan tidak berpengaruh signifikan terhadap kinerja . Sedangkan Wulandari dkk (2016) , Fahad (2013), dan Dewi (2012) membuktikan gaya kepemimpinan signifikan mempengaruhi kinerja.

Kinerja pemerintah saat ini banyak disoroti oleh masyarakat terutama kinerja instansi pemerintah yang sebagian besar kegiatannya dibiayai oleh dana publik begitu juga di Pemerintah Provinsi Jambi. Dalam LAKIP yang terpublikasi dari tahun 2015 hingga 2018 dipaparkan bahwa pada tahun 2018 terjadi penurunan persentase pencapaian APBD Pemerintah Provinsi Jambi secara keseluruhan jika dibandingkan dengan LAKIP sebelumnya. Ada beberapa bidang dan beberapa SKPD yang memiliki kemajuan dalam pencapaian realisasi anggarannya, namun tidak terlalu signifikan dibandingkan tahun sebelumnya. Untuk Pemerintah Provinsi Jambi, bedasarkan data APBD tahun 2015 s.d tahun 2018, secara keseluruhan masih terdapat beberapa program dan kegiatan yangmasih di bawah $70 \%$, yang masih kurang maksimal antara lain program pembinaan dan pengembangan aparatur yang realisasinya $56,47 \%$, kegiatan diklat penyusunan perencanaan tahunan setara $51,57 \%$, penyusunan renstra/RIPS SMK dan SIM SMK 50,46\%, kegiatan monitoring dan evaluasi dikmenti SMA/SMK 35,57\%, program peningkatan kelayakan pengoperasian kendaraan bermotor $60,46 \%$, kegiatan pengadaan dan pengamanan asset tanah milik Pemerintah sebesar 68,85\% (LAKIP, Provinsi jambi 2018).

Penelitian ini dirancang untuk menguji pengaruh partisipasi penyusunan $\mathrm{ABK}$ terhadap kinerja kepala SKPD pemerintah daerah, khususnya Pemerintah Provinsi Jambi. Dipilihnya partisipasi penyusunan ABK sebagai variabel independen dari penelitian ini didasarkan implikasi pendekatan partisipasi dalam sistem ABK sebagaimana Undang-Undang Nomor 23 Tahun 2014. Peneliti ingin mengetahui apakah partisipasi penyusunan $\mathrm{ABK}$ mendorong kinerja kepala SKPD pemerintah daerah untuk menyusun anggaran yang sebaik-baiknya.

Peneliti menduga komitmen organisasi dan gaya kepemimpinan menjadi variabel yang mempengaruhi hubungan antara partisipasi penyusunan ABK dan kinerja kepala SKPD pemerintah daerah. Komitmen organisasi yang kuat menyebabkan individu berusaha mencapai tujuan organisasi, berpikiran positif dan berusaha berbuat yang terbaik bagi organisasinya. Individu dengan komitmen organisasi yang rendah akan mementingkan diri dan kelompoknya sehingga memungkinkan untuk menciptakan rendahnya kinerja aparatur pemerintah daerah. Sedangkan keberhasilan dalam mengelola suatu organisasi tidak terlepas dari 
faktor kepemimpinan dan sikap bawahan dalam melaksanakan tugas mencapai tujuan organisasi.

\subsection{Rumusan Masalah}

Dari latar belakang yang diuraikan sebelumnya, maka penulis membuat rumusan masalah sebagai berikut:

1. Apakah partisipasi penyusunan $\mathrm{ABK}$ berpengaruh terhadap kinerja kepala SKPD pemerintah daerah ?

2. Apakah komitmen organisasi dapat memoderasi pengaruh partisipasi penyusunan $\mathrm{ABK}$ terhadap kinerja kepala SKPD pemerintah daerah ?

3. Apakah gaya kepemimpinan dapat memoderasi pengaruh partisipasi penyusunan $\mathrm{ABK}$ terhadap kinerja kepala SKPD pemerintah daerah ?

\subsection{Maksud dan Tujuan Penelitian}

Penelitian ini bermaksud untuk menguji pendekatan partisipatif sebagai implikasi penerapan UU No. 24/2014, PP No. 58/2005 dan Permendagri No. 13 Tahun 2006 terhadap timbulnya komitmen organisasi dan gaya kepemimpinan kemudian menguji ketiga variabel tersebut terhadap kinerja kepala SKPD pemerintah daerah.

Tujuan dari penelitian ini adalah:

1. Untuk mengetahui pengaruh partisipasi penyusunan ABK terhadap kinerja kepala SKPD pemerintah daerah.

2. Untuk mengetahui pengaruh komitmen organisasi dalam memoderasi pengaruh partisipasi penyusunan ABK terhadap kinerja kepala SKPD pemerintah daerah.

3. Untuk mengetahui pengaruh gaya kepemimpinan dalam memoderasi pengaruh partisipasi penyusunan ABK terhadap kinerja kepala SKPD pemerintah daerah.

\subsection{Kegunaan Penelitian}

\subsubsection{Aspek Teoritis}

Penelitian ini diharapkan dapat memberikan kontribusi pada pengembangan teori, terutama yang berkaitan dengan akuntansi sektor publik, akuntansi manajemen dan akuntansi keperilakuan. Kegunaan penelitian dalam aspek teoritis adalah untuk mengetahui secara empiris pengaruh partisipasi penyusunan $\mathrm{ABK}$ terhadap komitmen organisasi dan gaya kepemimpinan.

\subsubsection{Aspek Praktis}

1. Peneliti lainnya sebagai bahan referensi berkaitan dengan keperilakuan, khususnya perilaku aparatur daerah dalam penyusunan $\mathrm{ABK}$.

2. Pemerintah Daerah Provinsi Jambi, dalam rangka menjalankan tugas profesionalnya, khususnya dalam upaya peningkatan sumber daya aparatur dan program peningkatan komitmen organisasi dan gaya kepemimpinan yang tepat dan efektif sehingga dalam penyusunan $\mathrm{ABK}$ menjadi lebih berkualitas.

3. Pemerintah Pusat, Lembaga Tinggi Negara dan Organisasi Profesi, dalam membuat kebijakan atau aturan-aturan, berkaitan dengan sistem, standar, monitoring, evaluasi dan pemeriksaan sehingga dapat mendukung terciptanya $\mathrm{ABK}$ yang berkualitas.

\section{KAJIAN PUSTAKA, KERANGKA PEMIKIRAN DAN HIPOTESIS}

\subsection{Kajian Pustaka}

\subsubsection{Pengertian Kinerja}

Menurut Sadeli (2010:19) kinerja adalah suatu pernyataan akuntansi manajemen yang akan membandingkan secara aktual antara suatu aktivitas dengan suatu standar. Secara umum dapat juga dikatakan kinerja merupakan prestasi yang dapat dicapai oleh organisasi dalam periode tertentu (Indra Bastian, 2010:329).

\subsubsection{Partisipasi Penyusunan Anggaran Berbasis Kinerja}

Pengertian partisipasi menurut Mulyadi (2010: 513) adalah suatu proses pengambilan keputusan bersama oleh dua pihak atau lebih yang mempunyai dampak langsung kepada pembuat keputusan tersebut di masa depan". Partisipasi anggaran adalah keikutsertaan para manajer dalam proses penyusunan anggaran termasuk dalam pengambilan keputusan.

\subsubsection{Komitmen Organisasi}

Komitmen organisasi merupakan tingkat sampai sejauh mana seorang karyawan memihak pada suatu organisasi tertentu dan tujuan-tujuannya, serta berniat untuk mempertahankan keanggotaannya dalam organisasi tersebut (Arfan Ikhsan dkk, 2010:55).

Komitmen organisasi merupakan nilai personal yang mengacu pada sikap loyal pada suatu organisasi. Komitmen organisasi terbangun apabila masing-masing individu mengembangkan tiga sikap yang saling berhubungan terhadap organisasi dan atau profesi, yang antara lain: Identifikasi (identification), Keterlibatan (involvement), dan Loyalitas (loyality).

\subsubsection{Gaya Kepemimpinan}

Gibson (2003) dalam Sudaryono (2014) mendefinisikan kepemimpinan sebagai usaha dengan menggunakan suatu gaya untuk mempengaruhi dan tidak memaksa guna memotivasi individu dalam mencapai beberapa tujuan atau sasaran. Kepemimpinan merupakan kemampuan untuk mempengaruhi sekelompok orang ke arah pencapaian tujuan. 


\subsection{Kerangka Pemikiran}

Beberapa penelitian menemukan bukti bahwa tindakan berupa partisipasi dalam menjalankan proses penyusunan anggaran merupakan suatu fungsi yang menyebabkan manajer tingkat bawah menerima dan mempunyai komitmen terhadap pencapaian tujuan (Kenis, 1979). Partisipasi penyusunan anggaran merupakan pendekatan yang secara umum dapat meningkatkan kinerja yang pada akhirnya dapat meningkatkan efektivitas organisasi.

Efek motivasi pada partisipasi anggaran secara bersama-sama akan menggerakkan pada tingginya kepuasan kerja (job satisfaction) karena bawahan dilibatkan dalam penetapan tujuan anggaran sehingga menimbulkan komitmen mereka untuk mencapai tujuan tersebut. Mowday et. al (1979) menyatakan, individu yang mempunyai komitmen yang tinggi terhadap tujuan anggaran akan berpandangan positif dan berbuat yang terbaik untuk mencapai tujuan tersebut.

Penerapan anggaran berbasis kinerja disadari memerlukan komitmen organisasi yang tinggi. Komitmen organisasi pada satu sisi ditinjau dari keinginan individu untuk berbuat yang terbaik bagi organisasinya (Mowday, 1979). Para manajer tingkat bawah mempunyai informasi yang lebih akurat daripada para atasannya mengenai kondisi-kondisi lokal pusat pertanggungjawaban yang dipimpinnya. Penelitian ini didasarkan pada gagasan bahwa para manajer bawah (manajer pusat pertanggunjawaban) seringkali memiliki informasi yang lebih baik mengenai level anggaran yang diperlukan untuk mendukung pelaksanaan aktivitas-aktivitas unit organisasinya daripada atasannya (manajer puncak). Oleh karena itu, para manajer bawahan akan berusaha untuk memberikan informasi tersebut ke dalam usulan anggarannya untuk menjamin bahwa mereka memperoleh sumber-sumber yang mencukupi untuk melaksanakan aktivitas-aktivitasnya.

\subsection{Hipotesis Penelitian}

Model penelitian sebagai dasar untuk mengajukan hipotesis dalam penelitian ini adalah sebagai berikut :

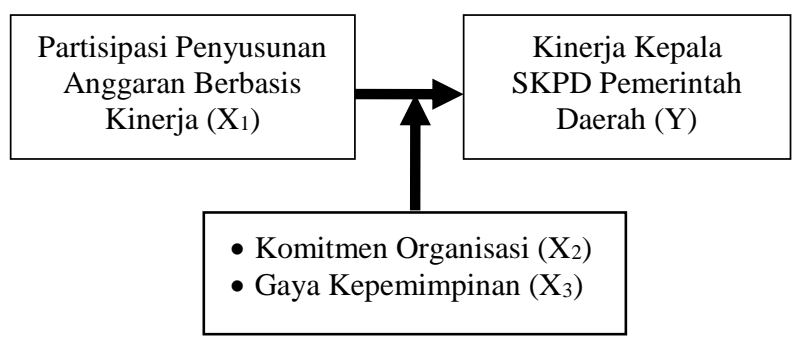

\section{Gambar 1. Model Penelitian}

$\mathrm{H}_{1}$ : Partisipasi penyusunan ABK berpengaruh terhadap kinerja kepala SKPD pemerintah daerah.

$\mathrm{H}_{2}$ : Komitmen organisasi dapat memoderasi pengaruh partisipasi penyusunan ABK terhadap kinerja kepala SKPD pemerintah daerah.
$\mathrm{H}_{3}$ : Gaya Kepemimpinan dapat memoderasi pengaruh partisipasi penyusunan $\mathrm{ABK}$ terhadap kinerja kepala SKPD pemerintah daerah.

\section{METODOLOGI PENELITIAN}

\subsection{Variabel Penelitian}

Variabel dalam penelitian ini adalah Partisipasi Penyusunan Anggaran Berbasis Kinerja, Komitmen Organisasi, Gaya Kepemimpinan Dan Kinerja Kepala SKPD Pemerintah Daerah.

\subsection{Metode Penelitian}

\subsubsection{Desain Penelitian}

Periode waktu yang digunakan adalah cross sectional yaitu (studi silang tempat) dilaksanakan satu kali dan mencerminkan potret dari suatu keadaan pada suatu saat tertentu Mudrajad Kuncoro (2013: 86).

Tipe hubungan antar variabel yang diteliti dalam penelitian ini berupa hubungan kausal.

\subsubsection{Operasionalisasi Variabel Partisipasi Penyusunan Anggaran Berbasis Kinerja $\left(\mathbf{X}_{1}\right)$}

Variabel partisipasi penyusunan anggaran berbasis kinerja $\left(\mathrm{X}_{1}\right)$ dibagi dalam dua dimensi yaitu: tingkat partisipasi aparat dan tingkat pengaruh aparat dalam memutuskan anggaran. Dimensi kemudian diukur dengan menggunakan indikator lima pertanyaan yang dikembangkan oleh Kenis (1979). Skala ini diperlakukan sebagai skala ordinal dengan gradasi 1 hingga 5 dengan atribut berkutub dua (bipolar) seperti Tidak Dilibatkan (skor 1) hingga Sangat Dilibatkan (skor 5). Skor tertinggi menunjukkan tingginya tingkat partisipasi penyusunan anggaran.

1) Komitmen organisasi $\left(X_{2}\right)$

Variabel komitmen organisasi $\left(\mathrm{X}_{2}\right)$ dibagi dalam dua dimensi yaitu: komitmen anggota terhadap organisasi dan komitmen organisasi kepada anggota. Dimensi kemudian diukur dengan menggunakan indikator sembilan pertanyaan yang dikembangkan oleh Mowday et. al (1979) dan Wiener (1982). Skala ini diperlakukan sebagai skala ordinal dengan gradasi 1 hingga 5 dengan atribut berkutub dua (bipolar) seperti Menolak (skor 1) hingga Menerima (skor 5). Skor tertinggi menunjukkan tingginya komitmen organisasi.

b) Gaya Kepemimpinan $\left(\mathrm{X}_{3}\right)$

Variabel gaya kepemimpinan $\left(\mathrm{X}_{3}\right)$ dibagi dalam dua dimensi yaitu: berorientasi pada orang dan berorientasi pada tugas. Dimensi kemudian diukur dengan menggunakan indikator delapan pertanyaan yang dikembangkan oleh Quey-Jen Yeh (1996). Skala ini diperlakukan sebagai skala ordinal dengan gradasi 1 hingga 5 dengan atribut berkutub dua (bipolar) seperti Tidak Pernah (skor 1) hingga Selalu (skor 5). Skor tertinggi menunjukkan tingginya gaya kepemimpinan. 
c) Kinerja Kepala SKPD Pemerintah Daerah (Y)

Variabel kinerja kepala SKPD pemerintah daerah (Y) diukur dengan menggunakan indikatorindikator yang dikembangkan oleh Mahoney et. al (1963) yang meliputi delapan bidang aktivitas manajemen, yaitu perencanaan, investigasi, pengkoordinasian, evaluasi, pengawasan, pengaturan staf, negosiasi dan perwakilan. Skala ini diperlakukan sebagai skala ordinal dengan gradasi 1 hingga 5 dengan atribut berkutub dua (bipolar) seperti Rendah (skor 1) hingga Tinggi (skor 5). Skor tertinggi menunjukkan tingginya kinerja kepala SKPD pemerintah daerah.

\subsubsection{Unit Analisis, Populasi Sasaran, dan Sampel Penelitian}

1) Unit Analisis

Unit analisis adalah satuan tertentu yang diperhitungkan sebagai subyek penelitian (Suharsimi, 2013: 121). Berdasarkan pengertian tersebut, maka unit analisis dalam penelitian ini adalah aparatur SKPD di lingkungan Pemerintah Daerah Provinsi Jambi.

Responden dalam penelitian ini untuk variabel $\mathrm{X}_{1}, \mathrm{X}_{2}$ dan $\mathrm{X}_{3}$ adalah kepala dinas/kantor/badan dan kepala subdinas/bagian/bidang dari dinas, kantor dan badan (SKPD) di Pemerintah Provinsi Jambi. Pemilihan responden tersebut dilakukan dengan alasan instansi tersebut merupakan satuan kerja pemerintah yang menyusun, menggunakan dan melaporkan realisasi anggaran pemerintah daerah. Sedangkan responden untuk variabel $\mathrm{Y}$ dibagi menjadi dua kelompok yaitu:
a. Bawasda (Badan Pengawas Daerah)
b. Inspektorat Propinsi

2) Populasi dan Sampel Penelitian

Populasi sasaran dalam penelitian ini adalah aparatur SKPD pemerintah Provinsi Jambi yang dilibatkan dalam menyusun RKA-SKPD. Populasi sasaran dalam penelitian ini adalah aparatur SKPD pemerintah Provinsi Jambi yang dilibatkan dalam menyusun RKA-SKPD dengan 350 orang dengan ekstimasi 7-9 orang per SKPD nya. Peneliti mengambil jumlah sampel 2 orang aparatur utama dalam SKPD yang bertanggungjawab atas pelaksanaan anggaran per SKPD yang terdiri atas kepala dinas /kantor / badan dan kepala subdinas / bagian/ bidang keuangan total sampel yang diambil sebanyak sekitar 88 orang.

3) Prosedur Pengumpulan Data

Pengumpulan data dalam penelitian ini dilakukan dengan dua cara yaitu:

a. Penelitian Lapangan

Sumber data yang akan digunakan dan dianalisis dalam penelitian ini adalah data primer yang diperoleh dari jawaban responden melalui penyebaran kuesioner kepada aparatur SKPD.

b. Penelitian Kepustakaan

Untuk melengkapi data yang diperoleh dari penelitian lapangan, maka diperlukan data pendukung yang diperoleh melalui studi pustaka yang berkaitan dengan penelitian ini melalui buku-buku, jurnal-jurnal yang berkaitan dengan permasalahan dalam penelitian ini.

\subsubsection{Metode Analisis dan Pengujian Hipotesis}

1) Metode Pengujian Data

Dalam suatu penelitian, kesimpulan yang diambil akan sangat tergantung pada kualitas data yang dianalisis dan instrumen yang digunakan untuk mengumpulkan data penelitian, karena itu ada dua konsep yang dapat digunakan untuk mengukur kualitas data, yaitu: reliabilitas dan validitas. Jika alat ukur yang digunakan tidak sahih dan tidak andal, maka hasilnya tidak menggambarkan keadaan yang sesungguhnya. Untuk itu diperlukan dua pengujian uji kesahihan (test of validity) dan uji keandalan (test of reliability).

2) Metode Transformasi Data

Penelitian ini menggunakan alat analisis regresi yang hanya dapat diolah jika menggunakan skala metrik (interval atau rasio). Oleh karena itu variabel independen yang menggunakan skala ordinal terlebih dahulu dikonversikan ke skala interval melalui metode interval berurutan (method of successive interval).

Data yang telah diolah melalui proses interval, selanjutnya dianalisis dengan menggunakan SPSS untuk mendapatkan nilai matriks korelasi antar variabel penelitian.

3) Metode Analisis Data

Metode analisis data yang digunakan dalam penelitian ini adalah analisis regresi berganda (Multiple Regression Analysis) dengan metode kuadrat terkecil atau Ordinary Least Square (OLS). Analisis tersebut dapat digunakan sebagai model prediksi terhadap suatu variabel dependen dari beberapa variabel independen, dengan model analisis sebagai berikut:

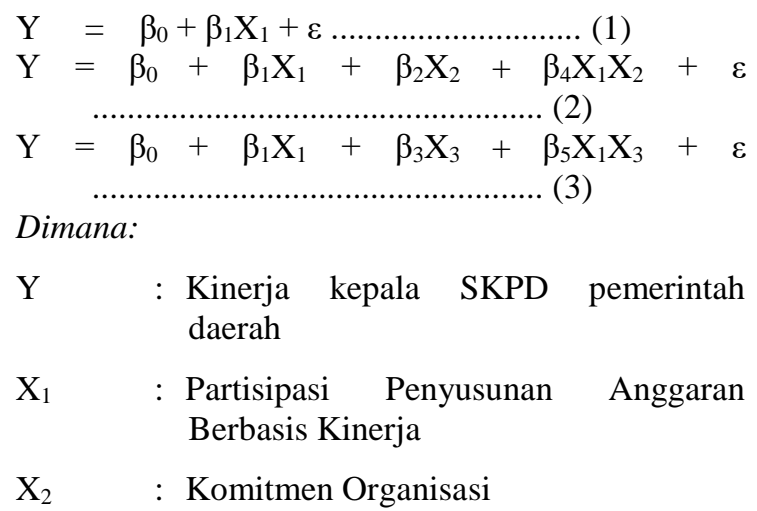




\author{
$\mathrm{X}_{3} \quad$ : Gaya Kepemimpinan \\ $\mathrm{X}_{1} \mathrm{X}_{2}$ : Interaksi antara Partisipasi Penyusunan \\ Anggaran Berbasis Kinerja dengan \\ Komitmen Organisasi \\ $\mathrm{X}_{1} \mathrm{X}_{3}$ : Interaksi antara Partisipasi Penyusunan \\ Anggaran Berbasis Kinerja dengan \\ Gaya Kepemimpinan

$\begin{array}{ll}\beta_{0} & : \text { Konstanta } \\ \beta_{1-5} & : \text { Koefisien Regresi } \\ \varepsilon & : \text { Error term }\end{array}$

Proses pengujian asumsi klasik statistik dilakukan bersama-sama dengan proses uji regresi sehingga langkah-langkah yang dilakukan dalam pengujian asumsi klasik statistik menggunakan media kotak kerja yang sama dengan uji regresi SPSS.

Dalam penelitian ini, asumsi klasik non autokorelasi tidak diuji dengan alasan karena data yang akan dikumpulkan dan diolah merupakan data cross section. Sedangkan masalah autokorelasi sering terjadi pada data time series. Dengan demikian, dalam penelitian ini asumsi model regresi yang akan diuji adalah pengujian disturbance error (normalitas), heteroskedastisitas dan multikolinieritas.

\section{a. Uji Normalitas}

Uji normalitas bertujuan untuk menguji apakah dalam model regresi variabel dependen dan variabel independen keduanya memiliki distribusi normal atau tidak. Model regresi yang baik adalah memiliki distribusi data normal atau mendekati normal.

b. Uji Heteroskedastisitas

Heteroskedastisitas menguji terjadinya perbedaan variance residual suatu periode pengamatan ke periode pengamatan yang lain, atau gambaran hubungan antara nilai yang diprediksi dengan Studentized Delete Residual nilai tersebut. Model regresi yang baik adalah model regresi yang memiliki persamaan variance residual suatu periode pengamatan dengan periode pengamatan yang lain, atau adanya hubungan antara nilai tersebut sehingga dapat dikatakan model tersebut homoskedastisitas.

c. Uji Multikolinieritas

Uji multikolinieritas diperlukan untuk mengetahui ada tidaknya variabel independen yang memiliki kemiripan dengan variabel independen lain dalam satu model. Kemiripan antar variabel independen dalam suatu model akan menyebabkan terjadinya korelasi yang sangat kuat antara suatu variabel independen dengan variabel independen yang lain. Selain itu, deteksi terhadap multikolinieritas juga bertujuan untuk menghindari kebiasan dalam proses pengambilan kesimpulan mengenai pengaruh pada uji parsial masing-masing variabel independen terhadapvariabel dependen.

4) Pengujian Hipotesis

Pengujian dan perhitungan yang dilakukan terdiri atas:

a. Uji Koefisien Determinasi $\left(\mathrm{R}^{2}\right)$

Uji koefisien determinasi $\left(\mathrm{R}^{2}\right)$ dilakukan untuk melihat besar variasi dari variabel independen secara bersama-sama dalam mempengaruhi variabel dependen. Nilai $\mathrm{R}^{2}$ berada antara 0 dan 1. Semakin mendekati nilai 1 atau $100 \%$, maka semakin besar pengaruh variabel independen terhadap variabel dependen.

b. Uji Statistik $\mathrm{t}$

Uji statistik $\mathrm{t}$ digunakan untuk melihat signifikansi pengaruh masing-masing variabel independen secara parsial terhadap variabel dependen dengan kriteria keputusan:

- Jika $\mathrm{t}$ hitung $\leq \mathrm{t}$ tabel $: \mathrm{H}_{0}$ diterima dan $\mathrm{H}_{1}$ ditolak.

- Jika $\mathrm{t}$ hitung $>\mathrm{t}$ tabel $: \mathrm{H}_{0}$ ditolak dan $\mathrm{H}_{1}$ diterima

\section{HASIL DAN PEMBAHASAN}

\subsection{Hasil Uji Validitas dan Reliabilitas}

Tabel 1. Hasil Uji Validitas terhadap Item Pertanyaan Partisipasi Penyusunan Anggaran Berbasis Kinerja

\begin{tabular}{|c|c|c|c|}
\hline $\begin{array}{c}\text { Item } \\
\text { Pertanyaan }\end{array}$ & r-hitung & r-tabel & Keterangan \\
\hline $\mathbf{1}$ & $\mathbf{0 , 7 0 8}$ & $\mathbf{0 , 2 0 9 6}$ & Valid \\
\hline $\mathbf{2}$ & $\mathbf{0 , 3 8 7}$ & $\mathbf{0 , 2 0 9 6}$ & Valid \\
\hline 3 & $\mathbf{0 , 6 8 5}$ & $\mathbf{0 , 2 0 9 6}$ & Valid \\
\hline 4 & $\mathbf{0 , 6 4 4}$ & $\mathbf{0 , 2 0 9 6}$ & Valid \\
\hline $\mathbf{5}$ & $\mathbf{0 , 4 8 3}$ & $\mathbf{0 , 2 0 9 6}$ & Valid \\
\hline
\end{tabular}

Sumber: Data primer yang diolah

Berdasarkan hasil pengujian pada tabel 1 setiap item pertanyaan menghasilkan koefisien korelatif yang lebih besar dari nilai r-tabel. Oleh karena itu, instrumen penelitian yang berjumlah lima pertanyaan ini dinilai telah mampu mengukur variabel partisipasi penyusunan anggaran berbasis kinerja.

Tabel 2 berikut ini menyajikan hasil reliabilitas terhadap item pertanyaan terkait dengan partisipasi penyusunan anggaran berbasis kinerja: 
Tabel 2. Hasil Uji Reliabilitas terhadap Item Pertanyaan Partisipasi Penyusunan Anggaran Berbasis Kinerja

Reliability Statistics

\begin{tabular}{|r|c|}
\hline Cronbach's Alpha & N of Items \\
\hline .789 & \\
\hline
\end{tabular}

Sumber: Data primer yang diolah

Hasil pengujian terhadap reliabilitas kuesioner di atas menghasilkan angka Crobanch Alpha lebih besar dari 0,60 yaitu sebesar 0,789. Oleh karena itu, dapat dinyatakan bahwa semua pertanyaan dari variabel partisipasi penyusunan anggaran berbasis kinerja dapat dinyatakan reliabel.

\subsection{Hasil Uji Validitas dan Reliabilitas Variabel Komitmen Organisasi}

Tabel 3 berikut ini menyajikan hasil uji validitas terhadap item pertanyaan komitmen organisasi:

Tabel 3. Hasil Uji Validitas terhadap Item Pertanyaan Komitmen Organisasi

\begin{tabular}{|c|c|c|c|}
\hline $\begin{array}{c}\text { Item } \\
\text { Pertanyaan }\end{array}$ & r-hitung & r-tabel & Keterangan \\
\hline $\mathbf{1}$ & $\mathbf{0 , 3 5 5}$ & $\mathbf{0 , 2 0 9 6}$ & Valid \\
\hline $\mathbf{2}$ & $\mathbf{0 , 5 2 9}$ & $\mathbf{0 , 2 0 9 6}$ & Valid \\
\hline $\mathbf{3}$ & $\mathbf{0 , 4 9 2}$ & $\mathbf{0 , 2 0 9 6}$ & Valid \\
\hline $\mathbf{4}$ & $\mathbf{0 , 4 9 0}$ & $\mathbf{0 , 2 0 9 6}$ & Valid \\
\hline $\mathbf{5}$ & $\mathbf{0 , 2 2 8}$ & $\mathbf{0 , 2 0 9 6}$ & Valid \\
\hline $\mathbf{6}$ & $\mathbf{0 , 4 5 9}$ & $\mathbf{0 , 2 0 9 6}$ & Valid \\
\hline $\mathbf{7}$ & $\mathbf{0 , 4 4 7}$ & $\mathbf{0 , 2 0 9 6}$ & Valid \\
\hline $\mathbf{8}$ & $\mathbf{0 , 3 9 3}$ & $\mathbf{0 , 2 0 9 6}$ & Valid \\
\hline $\mathbf{9}$ & $\mathbf{0 , 3 8 9}$ & $\mathbf{0 , 2 0 9 6}$ & Valid \\
\hline
\end{tabular}

Sumber: Data primer yang diolah

Berdasarkan hasil pengujian pada tabel 3 setiap item pertanyaan menghasilkan koefisien korelatif yang lebih besar dari nilai r-tabel. Oleh karena itu, instrumen penelitian yang berjumlah sembilan pertanyaan ini dinilai telah mampu mengukur variabel komitmen organisasi.

Tabel 4 berikut ini menyajikan hasil reliabilitas terhadap item pertanyaan terkait dengan komitmen organisasi.

Tabel 4. Hasil Uji Reliabilitas terhadap Item Pertanyaan Komitmen Organisasi

Reliability Statistics

\begin{tabular}{|r|r|}
\hline Cronbach's Alpha & N of Items \\
\hline .738 & \\
\hline
\end{tabular}

Sumber: Data primer yang diolah

Hasil pengujian terhadap reliabilitas kuesioner di atas menghasilkan angka Crobanch Alpha lebih besar dari 0,60 yaitu sebesar 0,738 . Oleh karena itu, dapat dinyatakan bahwa semua pertanyaan dari variabel komitmen organisasi dapat dinyatakan reliabel.

\subsection{Hasil Uji Validitas dan Reliabilitas Variabel} Gaya Kepemimpinan

Tabel 5 berikut ini menyajikan hasil uji validitas terhadap item pertanyaan gaya kepemimpinan:

Tabel 5. Hasil Uji Validitas terhadap Item Pertanyaan Gaya Kepemimpinan

\begin{tabular}{|c|c|c|c|}
\hline $\begin{array}{c}\text { Item } \\
\text { Pertanyaan }\end{array}$ & r-hitung & r-tabel & Keterangan \\
\hline $\mathbf{1}$ & $\mathbf{0 , 4 8 0}$ & $\mathbf{0 , 2 0 9 6}$ & Valid \\
\hline $\mathbf{2}$ & $\mathbf{0 , 5 7 2}$ & $\mathbf{0 , 2 0 9 6}$ & Valid \\
\hline $\mathbf{3}$ & $\mathbf{0 , 4 6 2}$ & $\mathbf{0 , 2 0 9 6}$ & Valid \\
\hline $\mathbf{4}$ & $\mathbf{0 , 4 5 2}$ & $\mathbf{0 , 2 0 9 6}$ & Valid \\
\hline $\mathbf{5}$ & $\mathbf{0 , 4 4 0}$ & $\mathbf{0 , 2 0 9 6}$ & Valid \\
\hline $\mathbf{6}$ & $\mathbf{0 , 2 9 8}$ & $\mathbf{0 , 2 0 9 6}$ & Valid \\
\hline $\mathbf{7}$ & $\mathbf{0 , 3 2 7}$ & $\mathbf{0 , 2 0 9 6}$ & Valid \\
\hline $\mathbf{8}$ & $\mathbf{0 , 2 7 7}$ & $\mathbf{0 , 2 0 9 6}$ & Valid \\
\hline
\end{tabular}

Sumber: Data primer yang diolah

Berdasarkan hasil pengujian pada tabel 5 setiap item pertanyaan menghasilkan koefisien korelatif yang lebih besar dari nilai r-tabel. Oleh karena itu, instrumen penelitian yang berjumlah delapan pertanyaan ini dinilai telah mampu mengukur variabel gaya kepemimpinan.

Tabel 6 berikut ini menyajikan hasil reliabilitas terhadap item pertanyaan terkait dengan gaya kepemimpinan:

Tabel 6. Hasil Uji Reliabilitas terhadap Item Pertanyaan Gaya Kepemimpinan

Reliability Statistics

\begin{tabular}{|c|c|}
\hline Cronbach's Alpha & $\mathrm{N}$ of Items \\
\hline .717 & 8 \\
\hline
\end{tabular}

Sumber: Data primer yang diolah

Hasil pengujian terhadap reliabilitas kuesioner di atas menghasilkan angka Crobanch Alpha lebih besar dari 0,60 yaitu sebesar 0,717 . Oleh karena itu, dapat dinyatakan bahwa semua pertanyaan dari variabel gaya kepemimpinan dapat dinyatakan reliabel.

4.4. Hasil Uji Validitas dan Reliabilitas Variabel Kinerja Kepala SKPD Pemerintah Daerah

Tabel 7 berikut ini menyajikan hasil uji validitas terhadap item pertanyaan Kinerja Kepala SKPD pemerintah daerah:

\section{Tabel 7. Hasil Uji Validitas terhadap Item Pertanyaan Kinerja Kepala SKPD Pemerintah Daerah}

\begin{tabular}{|c|c|c|c|}
\hline $\begin{array}{c}\text { Item } \\
\text { Pertanyaan }\end{array}$ & r-hitung & r-tabel & Keterangan \\
\hline $\mathbf{1}$ & $\mathbf{0 , 6 9 6}$ & $\mathbf{0 , 2 0 9 6}$ & Valid \\
\hline $\mathbf{2}$ & $\mathbf{0 , 7 8 3}$ & $\mathbf{0 , 2 0 9 6}$ & Valid \\
\hline $\mathbf{3}$ & $\mathbf{0 , 5 0 5}$ & $\mathbf{0 , 2 0 9 6}$ & Valid \\
\hline $\mathbf{4}$ & $\mathbf{0 , 5 4 2}$ & $\mathbf{0 , 2 0 9 6}$ & Valid \\
\hline $\mathbf{5}$ & $\mathbf{0 , 5 2 6}$ & $\mathbf{0 , 2 0 9 6}$ & Valid \\
\hline 6 & $\mathbf{0 , 6 0 4}$ & $\mathbf{0 , 2 0 9 6}$ & Valid \\
\hline
\end{tabular}




\begin{tabular}{|l|l|l|l|}
\hline $\mathbf{7}$ & $\mathbf{0 , 7 1 0}$ & $\mathbf{0 , 2 0 9 6}$ & Valid \\
\hline $\mathbf{8}$ & $\mathbf{0 , 4 5 2}$ & $\mathbf{0 , 2 0 9 6}$ & Valid \\
\hline
\end{tabular}

Sumber: Data primer yang diolah

Berdasarkan hasil pengujian pada tabel 7 setiap item pertanyaan menghasilkan koefisien korelatif yang lebih besar dari nilai r-tabel. Oleh karena itu, instrumen penelitian yang berjumlah delapan pertanyaan ini dinilai telah mampu mengukur variabel kinerja kepala SKPD pemerintah daerah.

Tabel 8 berikut ini menyajikan hasil reliabilitas terhadap item pertanyaan terkait dengan kinerja kepala SKPD pemerintah daerah:

Tabel 8. Hasil Uji Reliabilitas terhadap Item Pertanyaan Kinerja Kepala SKPD Pemerintah Daerah

Reliability Statistics

\begin{tabular}{|r|r|}
\hline Cronbach's Alpha & N of Items \\
\hline .853 & \\
\hline
\end{tabular}

Sumber: Data primer yang diolah

Hasil pengujian terhadap reliabilitas kuesioner di atas menghasilkan angka Crobanch Alpha lebih besar dari 0,60 yaitu sebesar 0,853 . Oleh karena itu, dapat dinyatakan bahwa semua pertanyaan dari variabel kinerja kepala SKPD pemerintah daerah dapat dinyatakan reliabel.

\subsection{Metode Transformasi Data}

Teknik statistik yang digunakan dalam penelitian ini adalah statistik parametrik dimana salah satu asumsinya adalah minimal skala pengukurannya interval, sehingga data ordinal yang diperoleh dari hasil penelitian ditransformasikan terlebih dahulu menjadi data interval dengan menggunakan Method of Successive Interval (MSI). Adapun hasil data interval selengkapnya untuk variabel $\mathrm{X}_{1}, \mathrm{X}_{2}, \mathrm{X}_{3}$ dan $\mathrm{Y}$ dapat dilihat pada Lampiran.

\subsection{Pengujian Hipotesis}

\subsubsection{Hasil Uji Regresi Moderasi (Moderated Regression Analysis)}

Analisis regresi yang digunakan dalam penelitian ini adalah analisis regresi moderasi (Moderated Regression Analysis) untuk menganalisis tentang pengaruh partisipasi penyusunan anggaran berbasis kinerja terhadap kinerja kepala SKPD pemerintah daerah dengan komitmen organisasi dan gaya kepemimpinan sebagai variabel moderating. Hasil analisis regresi dapat di lihat pada tabel berikut:

Tabel 9. Hasil Uji Regresi Persamaan I

\begin{tabular}{|c|c|c|c|c|c|}
\hline \multirow{3}{*}{ Model } & \multicolumn{2}{|c|}{$\begin{array}{c}\text { Unstandardized } \\
\text { Coefficients }\end{array}$} & $\begin{array}{c}\text { Standardized } \\
\text { Coefficients }\end{array}$ & \multirow{2}{*}{$\mathrm{t}$} & \multirow{2}{*}{ Sig. } \\
\cline { 2 - 5 } & $\mathrm{B}$ & $\begin{array}{c}\text { Std. } \\
\text { Error }\end{array}$ & Beta & & \\
\hline (Constant) & 10.256 & 2.580 & & 3.976 & .000 \\
\hline
\end{tabular}

\begin{tabular}{|l|r|r|r|r|r|}
\hline $\begin{array}{l}\text { Partisipasi } \\
\text { Penyusunan } \\
\text { ABK }\end{array}$ & 1.151 & .165 & .602 & 6.984 & .000 \\
\hline
\end{tabular}

a. Dependent Variable: Kinerja Kepala SKPD Pemda

Sumber: Data primer yang diolah, 2019

Tabel 10. Hasil Uji Regresi Persamaan II

Coefficients $^{\mathrm{a}}$

\begin{tabular}{|c|c|c|c|c|c|}
\hline \multirow{2}{*}{ Model } & \multicolumn{2}{|c|}{$\begin{array}{c}\text { Unstandardized } \\
\text { Coefficients }\end{array}$} & \multirow{2}{*}{$\begin{array}{c}\begin{array}{c}\text { Standardized } \\
\text { Coefficients }\end{array} \\
\text { Beta }\end{array}$} & \multirow{2}{*}{$\mathrm{t}$} & \multirow{2}{*}{ Sig. } \\
\hline & B & $\begin{array}{l}\text { Std. } \\
\text { Error }\end{array}$ & & & \\
\hline (Constant) & 8.385 & 3.520 & & 2.382 & .019 \\
\hline Partisipasi & 1.012 & .195 & .529 & 5.180 & .000 \\
\hline $\begin{array}{l}\text { Penyusunan } \\
\text { ABK }\end{array}$ & .674 & .217 & .321 & 3.106 & .003 \\
\hline Komitmen & & & & & \\
\hline $\begin{array}{l}\text { Organisasi } \\
\text { Efek }\end{array}$ & 501 & 217 & 225 & 3314 & 023 \\
\hline Moderasi & . & .211 & . $22 J$ & 2.514 & .025 \\
\hline $\begin{array}{l}\text { Komitmen } \\
\text { Organisasi }\end{array}$ & & & & & \\
\hline
\end{tabular}

a. Dependent Variable: Kinerja Kepala SKPD Pemda

Sumber: Data primer yang diolah, 2019

Tabel 11. Hasil Uji Regresi Persamaan III

Coefficients $^{\text {a }}$

\begin{tabular}{|c|c|c|c|c|c|}
\hline \multirow{2}{*}{ Model } & \multicolumn{2}{|c|}{$\begin{array}{c}\text { Unstandardized } \\
\text { Coefficients }\end{array}$} & \multirow{2}{*}{$\begin{array}{c}\begin{array}{c}\text { Standardized } \\
\text { Coefficients }\end{array} \\
\text { Beta }\end{array}$} & \multirow{2}{*}{$\mathrm{t}$} & \multirow{2}{*}{ Sig. } \\
\hline & B & $\begin{array}{l}\text { Std. } \\
\text { Error }\end{array}$ & & & \\
\hline (Constant) & 14.888 & 4.406 & & 3.379 & .001 \\
\hline Partisipasi & 1.169 & .161 & .611 & 7.244 & .000 \\
\hline $\begin{array}{l}\text { Penyusunan } \\
\text { ABK } \\
\text { Gaya } \\
\text { Kepemimpi } \\
\text { nan }\end{array}$ & .430 & .190 & .190 & 2.258 & .027 \\
\hline $\begin{array}{l}\text { Efek } \\
\text { Moderasi } \\
\text { Gaya } \\
\text { Kepemimpi } \\
\text { nan }\end{array}$ & .082 & .081 & .085 & 1.008 & .316 \\
\hline
\end{tabular}

a. Dependent Variable: Kinerja Kepala SKPD Pemda

Sumber: Data primer yang diolah, 2019

\subsubsection{Hasil Uji Koefisien Determinasi (R-Square)}

Koefisien determinasi pada intinya menyatakan seberapa baik suatu model untuk menjelaskan variasi variabel dependen (Ghozali, 2016). Nilai $\mathrm{R}^{2}$ yang semakin tinggi menjelaskan bahwa semakin cocok variabel independen menjelaskan variabel dependen. Semakin kecil nilai $\mathrm{R}^{2}$ berarti semakin sedikit kemampuan variabel-variabel independen untuk menjelaskan variabel dependen.

Tabel 12. Hasil Uji R-Square Persamaan I

\begin{tabular}{|l|c|r|r|r|}
\multicolumn{5}{|c|}{ Model Summary $^{\mathbf{b}}$} \\
Model & $\mathrm{R}$ & R Square & $\begin{array}{c}\text { Adjusted } \\
\text { R Square }\end{array}$ & $\begin{array}{c}\text { Std. Error of } \\
\text { the Estimate }\end{array}$ \\
\hline 1 & $.602^{\mathrm{a}}$ & .362 & .354 & 5.47311 \\
\hline
\end{tabular}

a. Predictors: (Constant), Partisipasi Penyusunan ABK

b. Dependent Variable: Kinerja Kepala SKPD Pemda

Tabel 12 menunjukkan bahwa nilai $R$-Square sebesar 0,362 . Ini berarti bahwa kemampuan variabel 
partisipasi penyusunan anggaran berbasis kinerja terhadap kinerja kepala SKPD pemerintah daera sebesar $36,2 \%$ dan sisanya dijelaskan oleh variabel lain di luar model.

Tabel 13. Hasil Uji R-Square Persamaan II Model Summary ${ }^{b}$

\begin{tabular}{|l|c|r|r|r|}
\hline Model & $\mathrm{R}$ & R Square & $\begin{array}{c}\text { Adjusted } \\
\text { R Square }\end{array}$ & $\begin{array}{c}\text { Std. Error of } \\
\text { the Estimate }\end{array}$ \\
\hline 1 & $.663^{\mathrm{a}}$ & .440 & .420 & 5.18952 \\
\hline
\end{tabular}

a. Predictors: (Constant), Efek Moderasi Komitmen Organisasi, Partisipasi Penyusunan ABK, Komitmen Organisasi

b. Dependent Variable: Kinerja Kepala SKPD Pemda

Tabel 13 menunjukkan bahwa nilai Adjusted $R$-Square sebesar 0,420 . Ini berarti bahwa kemampuan variabel komitmen anggaran terhadap kinerja kepala SKPD pemerintah daerah sebesar $42 \%$ dan sisanya dijelaskan oleh variabel lain di luar model.

Tabel 14. Hasil Uji R-Square Persamaan III

\begin{tabular}{|l|c|r|r|r|}
\hline Model & R & R Square & $\begin{array}{c}\text { Adjusted } \\
\text { R Square }\end{array}$ & $\begin{array}{c}\text { Std. Error of } \\
\text { the Estimate }\end{array}$ \\
\hline 1 & $.638^{\mathrm{a}}$ & .407 & .386 & 5.33877 \\
\hline
\end{tabular}

a. Predictors: (Constant), Efek Moderasi Gaya Kepemimpinan, Partisipasi Penyusunan ABK, Gaya Kepemimpinan

b. Dependent Variable: Kinerja Kepala SKPD Pemda

Tabel 14 menunjukkan bahwa nilai Adjusted $R$ Square sebesar 0,386 . Ini berarti bahwa kemampuan variabel gaya kepemimpinan terhadap kinerja kepala SKPD pemerintah daerah sebesar $38,6 \%$ dan sisanya dijelaskan oleh variabel lain di luar model.

\subsubsection{Hasil Uji Parsial (Uji t)}

Pengujian hipotesis pengaruh variabel partisipasi penyusunan anggaran berbasis kinerja terhadap kinerja kepala SKPD pemerintah daerah di tabel 4.15 diperoleh tingkat signifikansi sebesar 0,000 dan nilai signifikansi ini lebih kecil dari 0,000 $(\alpha=5 \%)$ maka $\mathrm{Ha}_{1}$ diterima. Hal ini berarti bahwa partisipasi penyusunan anggaran berbasis kinerja berpengaruh terhadap kinerja kepala SKPD pemerintah daerah.

\subsubsection{Hasil Uji Moderasi}

Pengujian hipotesis pengaruh variabel moderasi komitmen organisasi antara pengaruh partisipasi penyusunan anggaran berbasis kinerja terhadap kinerja kepala SKPD pemerintah daerah di tabel 4.16 diperoleh tingkat signifikansi sebesar 0,023 dan nilai signifikansi ini lebih kecil dari $0,05(\alpha=5 \%)$ maka $\mathrm{Ha}_{2}$ diterima yang berarti bahwa komitmen organisasi mampu memoderasi pengaruh partisipasi penyusunan anggaran berbasis kinerja terhadap kinerja kepala SKPD pemerintah daerah.
Pengujian hipotesis pengaruh variabel moderasi gaya kepemimpinan antara pengaruh partisipasi penyusunan anggaran berbasis kinerja terhadap kinerja kepala SKPD pemerintah daerah di tabel 4.17 diperoleh tingkat signifikansi sebesar 0,316 dan nilai signifikansi ini lebih besar dari 0,05 ( $\alpha=5 \%)$ maka $\mathrm{Ha}_{3}$ ditolak yang berarti bahwa gaya kepemimpinan tidak mampu memoderasi pengaruh partisipasi penyusunan anggaran berbasis kinerja terhadap kinerja kepala SKPD pemerintah daerah.

\subsection{Pembahasan}

Berdasarkan hasil pengolahan data di atas, dapat diketahui bahwa nilai $t_{\text {hitung }}$ partisipasi penyusunan ABK sebesar 0,000 dengan p-value $<0,05$, bahwa semakin tinggi tingkat partisipasi penyusunan ABK akan semakin tinggi pula tingkat kinerja kepala SKPD pemerintah daerah. Adanya pengaruh antara partisipasi penyusunan ABK terhadap kinerja kepala SKPD pemerintah daerah menunjukkan bahwa semakin tinggi partisipasi penyusunan ABK maka kecenderungan meningkatnya kinerja kepala SKPD pemerintah daerah. Semakin tinggi tingkat keterlibatan para aparatur dalam proses partisipasi penyusunan anggaran, maka semakin baik pula hasil kinerjanya.

Berdasarkan hasil pengolahan data di atas, dapat diketahui bahwa nilai $\left|t_{\text {hitung }}\right|$ interaksi antara partisipasi penyusunan ABK dengan komitmen organisasi sebesar 0,023 dengan p-value $<0,05$. Penelitian ini menerima $\mathrm{H}_{2}$. Hal ini berarti kombinasi kesesuaian antara partisipasi penyusunan $\mathrm{ABK}$ dan komitmen organisasi terhadap kinerja kepala SKPD pemerintah daerah merupakan terbaik. Hasil penelitian ini memperoleh dukungan yang signifikan terhadap hipotesis yang menyatakan bahwa komitmen organisasi mampu memoderasi pengaruh partisipasi penyusunan anggaran berbasis kinerja terhadap kinerja kepala SKPD pemerintah daerah.

Berdasarkan hasil pengolahan data di atas, dapat diketahui bahwa nilai $\left|t_{\text {hitung }}\right|$ interaksi antara partisipasi penyusunan $\mathrm{ABK}$ dengan gaya kepemimpinan sebesar 0,316 dengan p-value $<0,05$. Penelitian ini menolak $\mathrm{H}_{3}$. Hal ini berarti kombinasi kesesuaian antara partisipasi penyusunan ABK dan gaya kepemimpinan terhadap kinerja kepala SKPD pemerintah daerah merupakan kesesuaian yang kurang baik. Hasil penelitian ini tidak memperoleh dukungan gaya kepemimpinan mampu memoderasi pengaruh partisipasi penyusunan anggaran berbasis kinerja terhadap kinerja kepala SKPD pemerintah daerah

\section{SIMPULAN DAN SARAN}

\subsection{Kesimpulan}

Hasil penelitian ini adalah partisipasi penyusunan anggaran berpengaruh terhadap Kinerja Kepala SKPD Pemerintah Daerah, Komitmen Organisasi mampu memoderasi mengenai pengaruh partisipasi penyusunan anggaran terhadap Kinerja Kepala SKPD Pemerintah 
Daerah. Namun, gaya kepemimpinan tidak mampu memoderasi pengaruh partisipasi penyusunan anggaran terhadap Kinerja Kepala SKPD Pemerintah Daerah.

\subsection{Saran}

Penting bagi Pemerintah Provinsi Jambi untuk meningkatkan kualitas partisipasi aparatur, komitmen organisasi dan gaya kepemimpinan yang tepat dan efektif melalui proses rekruitmen yang selektif, perhatian terhadap kesejahteraan pegawai, lingkungan kerja yang kondusif dan kepastian pengembangan karir serta menjalin hubungan kerja yang harmonis antara atasan dan bawahan, sehingga dapat disusun anggaran berbasis kinerja (ABK) yang berkualitas sesuai visi dan misi Provinsi Jambi. Penelitian selanjutnya diharapkan menguji kembali faktor tersebut dengan unit pengamatan yang lebih luas. Sementara itu, keterbatasan penelitian ini sebagai berikut:

1. Data dalam penelitian ini dikumpulkan dengan metode survey yang dilakukan dengan menyebarkan kuesioner kepada responden. Pertanyaan kuesioner untuk beberapa indikator yang bersifat kualitatif dapat saja menimbulkan jawaban yang sifatnya persepsi. Namun peneliti mencoba meminimalkan masalah ini dengan Selain itu, penggunaan skala semantic differential bipolar dianggap sebagai solusi yang mampu memberikan ruang bagi responden untuk menyatakan fakta.

2. Dalam penelitian ini penulis hanya memasukkan dua variabel moderating yang memoderasi hubungan partisipasi penyusunan ABK dan kinerja kepala SKPD pemerintah daerah yaitu komitmen organisasi dan gaya kepemimpinan.

\section{DAFTAR REFERENSI}

Arfan Ikhsan dan Ishak. 2010. Akuntansi Keperilakuan. Jakarta: Salemba Empat.

Baihaqi. (2012). Pengaruh komitmen organisasi dan peran manajerial pengelolaan keuangan terhadap kinerja manajerial Satuan Kerja Perangkat Daerah. Jurnal Fairness Vol 1 No 3:243-253.

Darman, Baharuddin, 2015. The Effect of Budgetary Participation, Budget Goal Clarity, Decentralized Structure, and Public Accountability on the Perforppppmance of Regional Work Units (SKPD) at Gowa District, Sulawesi Selatan. Scientific Research

Dewi, Sarita Permata. 2012. Pengaruh Pengendalian Internal Dan Gaya Kepemimpinan Terhadap Kinerja Karyawan SPBU Yogyakarta. Jurnal Nominal, Vol: 1, No. 1, 5-17.

Eka, Zuwesty Putri dan Adiguna, Ricky. 2014. "Pengaruh Partisipasi Penyusunan Anggaran, Komitmen Organisasi, Gaya Kepemimpinan
Terhadap Kinerja Manajerial”. Dalam ESENSI Jurnal Bisnis dan Manajemen, Vol. 4, No. 3.

Fahad, Landjar, dan Fathurrohman. 2013. Pengaruh Gaya Kepemimpinan Dan Motivasi Terhadap Kinerja Pegawai Pada Biro Tata Pemerintah Sekretariat Daerah Provinsi Jawa Tengah. Artikel(http://download.portalgaruda.org/article.p hp? article $=73058 \&$ val=49 25)

Fitri, Tengku Ramona. 2016. "Pengaruh Budgetary Goal Characteristics, Kompensasi Terhadap Kinerja Parat Pemda Dengan Motivasi Sebagai Variabel Moderasi (Studi Kasus pada Dinas-dinas Kabupaten Rokan Hilir". JOM FEKON. Vol. 3 No. 1. h: 520-534.

Hashim, A.W., I. Hanafi, A. Fitrianto and H. Darwish. 2014. Roles of Budgetary Participation on Leader's Performance: A Study Case in Ternate. Asian Social Science, 10 (12).

Kenis, Izzetin. 1979. The Effect of Budgetary Goal Characteristics on Managerial Attitudes and Performance. The Accounting Review (April), Vol. LIV, 4, 707-721.

Kewo, Cecilia, Lelly, 2014. The Effect of Participative Budgeting, Budget Goal Clarity and Internal Control Implementation on Managerial Performance. Research Journal of Finance and Accounting. ISSN 2F222-1697 Vol.5, No.12

Kholidah, L.A., dan Murtini, H. (2014). Partisipasi Anggaran terhadap kinerja manajerial: Komitmen organisasi dan informasi tugas sebagai pemediasi Accounting Analysis Journal.

Kuncoro Mudrajad. 2013. Metode Riset untuk Bisnis \& Ekonomi: Bagaimana Meneliti \& Menulis Tesis?. Jakarta: Erlangga.

Mahoney, T. A., T. H. Jerdee and S. J. Carroll. 1963. Development of Managerial Performance: A Research Approach. Cincinnati, Ohio: South Western Publishing Co.

Mowday, R. T. 1979. Leader Characteristics, SelfConfidence, and Methods of Upward Influence in Organizational Decision Situations. Academy of Management Journal. Vol. 22, No. 4, 709-725.

Mulyadi, 2010. Akuntansi Biaya. Yogyakarta: Unit Penerbit dan Percetakan Sekolah Tinggi Ilmu Manajemen YKPN.

Noor, I.H.M. and R. Othman. 2012. Budgetary Participation: How It Affects Performance and Commitment. Accountancy Business and the Public Interest, pp.53-73.

Nor, Wahyudian, (2007). Desentralisasi dan Gaya Kepemimpinan Sebagai Variabel Moderating Dalam Hubungan Antara Partisipasi Penyusunan Anggaran dan Kinerja Manajerial. Simposium Nasional Akuntansi X, Makassar. 
Rachman, A.A. 2014. The Effect of Organization Commitment and Procedural Fairness on Participative Budgeting and Its Implication to Performance Moderating by Management Accounting Information (A Survey on Province Local Government Unit Agencies of West Java), Review of Integrative Business \& Economics Research, vol. 3 no. 1

Raghunandan, M.,Narendra Ramgulam,and Kishina Raghunan dan Mohammed. 2012. Examining the behavioural Aspects of Budgeting with Particular Empasis on Public Sector/Service. International Journal of Business and Social Science, 3(14), PP: 110-117

Sudaryono. (2014). Budaya \& Perilaku Organisasi, Edisi Pertama. Jakarta: Lentera Ilmu Cendekia.

Suharsimi Arikunto. 2013. Prosedur Penelitian: Suatu Pendekatan Praktek. Jakarta: Rineka Cipta.

Syahputra, Z. 2014. "Budget Participation on Managerial Performance: Related Factors in that influenced to Government's Employee (Study of Indonesian Local Government)", Journal of
Economics and Sustainable Development, Vol. 5 No. 21.

Utama, E.Y., dan Rohman, A. (2013). Pengaruh partisipasi penyusunan anggaran terhadap kinerja manajerial: Komitmen organisasi dan persepsi inovasi sebagai variabel intervening. Diponegoro Journal Of Accounting Volume 2, Nomor 3:1-12.

Wulandari, D.E., dan Riharjo, I.B. (2016). Pengaruh penganggaran partisipatif terhadap kinerja manajerial dengan komitmen organisasi dan gaya kepemimpinan sebagai variabel pemoderasi. Jurnal Ilmu dan Riset Akuntansi Volume 5, Nomor 4.

Yeh, Quey-Jen. 1996. The Link between Managerial Style and the Job Characteristics of the $R \& D$ Professionals. R \& D Management, 26 (1), 127140.

Yuniani, Evi. Saty, Fadila Marga. Dewi, Dian Nirmala. Komitmen organisasi dan gaya kepemimpinan dalam hubungan antara partisipasi anggaran dan kinerja manejerial. Laporan penelitian, politeknik negeri

2017. 